\title{
HYPERPYREXIA DURING ANAESTHESIA
}

\author{
SilVA HogG, M.D., DIP. ANAES., AND. WeLIS ReNWICK, M.D., F.H.C.P.(c)
}

EXTREME HYPERPYREXIA during anaesthesia occurs infrequently, but is a potentially fatal complication. In the past, when operating theatres were not air conditioned, hyperpyrexia was a more frequent complication during the summer months, and occurred chiefly in children and young adults. ${ }^{1}$ Recently there have been a few reports of hyperpyrexia during anaesthesia apparently unrelated to environmental factors. ${ }^{2-4}$ To the present time no common denominator of anaesthetic agent or combination of anaesthetic agents has been found. It is of interest that fatal hyperpyrexia has been reported as occurring during the use of antidepressants and in glutethamide poisoning. ${ }^{5-10}$

The paucity of reports in the literature has prompted us to examine here the following instance of fatal hyperpyrexia during anaesthesia.

\section{CASE REPORT}

The patient was a 22-year-old male, apparently in good general health. He was admitted to the hospital for surgical correction of equino-varus deformities of the feet.

Past history revealed that the patient was born with deformities of both feet, scoliosis, and a slight ptosis of the right eyelid. As a child he had been admitted to the Hospital for Sick Children on several occasions because of trouble with his feet, and he had had two uneventful anaesthetics for eye operations at the ages of 6 and 7 years. There was nothing else of significance in his past history.

\section{Family History}

The patient's father also had a mild deformity of the spine. Otherwise all members of the family including three siblings were healthy.

Physical examination revealed a generally healthy, somewhat thin but well developed young man with the musculoskeletal deformities previously mentioned. Examination was otherwise normal. $\mathrm{Hb}: 14.5 \mathrm{gm} ., \mathrm{WBC}$ : 10700, ESR: $17 \mathrm{~mm} . / \mathrm{hr}$.

The patient was premedicated with meperidine $75 \mathrm{mg}$. and atropine $0.4 \mathrm{mg}$. intramuscularly one hour prior to induction of anaesthesia. Upon arrival in the operating room his temperature was $97.4^{\circ} \mathrm{F}$, blood pressure $120 / 88$, pulse rate 90 per minute. Anaesthesia was induced with sodium thiopentone $250 \mathrm{mg}$. and maintained with nitrous oxide and oxygen (flow of 4 litres of each) and halothane in a semi-closed system with absorber in circuit and spontaneous respiration. An intravenous infusion of 5 per cent glucose in distilled water was started in the patient's left forearm. A tourniquet was applied to the patient's right thigh.

Twenty-five minutes after the induction of anaesthesia breathing became inadequate. The airway was checked but no obstruction was found, and repositioning 
of the patient's head did not correct the situation. At this time the patient appeared to have bronchospasm confirmed by auscultation of the chest. He was finally intubated without a relaxant, using a $9 \mathrm{~mm}$. Magill endotracheal tube, and respiration was assisted. Ether inhalations were tried to relieve the bronchospasm, without success. The patient appeared very flushed but was not perspiring. While the respiration was being assisted manually, it was noticed that the rebreathing bag and the soda-lime cannister were very warm. The patient's temperature was checked and recorded as $104^{\circ} \mathrm{F}$. Ether was discontinued and the patient was then given succinylcholine $20 \mathrm{mg}$. intravenously, with no effect. All anaesthetic agents were discontinued, and intermittent positive pressure ventilation with pure oxygen was continued. The temperature rose further to $108^{\circ} \mathrm{F}$., and a few minutes later to $110^{\circ} \mathrm{F}$. Artificial cooling with ice packs, alcohol sponges, and later colonic ice irrigation was started. The intravenous infusion solution was changed on the supposition that the original bottle might have contained pyrogens.

The pupils became dilated and did not react to light. The neck was rigid and extended. The arms and legs were held rigid with carpopedal spasm. The toes were upgoing. The abdominal muscles were rigid and the patient showed tremor and myoclonic movements. He later developed opisthotonos. The heart rate increased to 130 per minute, and this tachycardia was followed by bradycardia and arrhythmia. A systolic murmur developed. An E.C.G. was recorded, showing a varying pattern from right bundle branch block to ventricular tachycardia, and changes typical of myocardial ischaemia. The blood pressure remained around $130 / 90 \mathrm{~mm}$. Hg until terminally, when it suddenly fell and the heart arrested three hours and forty-five minutes after the induction of anaesthesia.

Other treatment during this period consisted of cortisone (Solucortef) $500 \mathrm{mg}$., tetracycline $275 \mathrm{mg}$, intravenously, and 10 per cent mannitol $1000 \mathrm{ml}$.

Terminally the rectal temperature was $104^{\circ} \mathrm{F}$.

Blood culture and cultures of all drugs used, of the intravenous solution used, and of all the syringes used showed no growth. All solutions were tested and were found free of pyrogens. Autopsy failed to show any specific lesions. There was some cerebral oedema, and petechial haemorrhages were found in the brain and mucous membranes.

\section{Discussion}

The degree of hyperpyrexia occurring in this case has been described as "hyperthermia," a condition reached when the mean temperature of the body is such that the continued functioning of some of the vital tissues is endangered thereby.

In a normal individual the body temperature is maintained at about $37^{\circ} \mathrm{C}$. When one speaks of body temperature one means usually the internal temperature of the body, the so-called core temperature. This core temperature is very accurately regulated, varying from the mean by not more than $1^{\circ} \mathrm{C}$. It represents the balance between heat production and heat loss from the body.

Heat Production is a reflection of the metabolic rate of the body. Factors influencing the metabolic rate are: $(a)$ the basal metabolic rate, which is usually in the vicinity of $40 \mathrm{Cal}$. of heat per square metre of body surface area per hour; 
(b) muscular activity due to exercise or shivering, which can increase the metabolic rate of the whole body up to $150-200$ per cent; (c) sympathetic activity which can increase the metabolic rate up to 50 per cent above normal; (d) increased thyroxin production and activity which can raise the metabolic rate about 100 per cent above normal; $(e)$ increased body temperature itself, which will cause an increased rate of heat production by the cells. The rate of heat production rises 13 per cent for each degree centigrade increase in body temperature.

Heat loss occurs by: (a) Radiation. The body loses heat in the form of infrared heat rays radiating in all directions from the body if the temperature of the body is greater than the temperature of the surrounding environment. If the surroundings become warmer than the body, more heat is transmitted to the body than from the body. (b) Conduction and convection. Usually only small quantities of heat are lost from the body by direct conduction. An object in contact with the body soon acquires the temperature of the body, and acts as an insulator thereafter. Convection is a type of conductive heat loss-removal of heat conducted to the air by air currents. (c) Evaporation. Sixty-four hundredths of a Calorie of heat is lost for each gramme of water evaporated from the body surface. Six hundred $\mathrm{ml}$. of water per day is lost insensibly from the skin and lungs. Evaporative loss of heat is very important when the temperature of the surroundings is greater than the temperature of the body. Under such conditions, this is the only means by which the body can lose some heat. Absence of sweating can be disastrous in cases of high temperature within or outside of the body, or both. Sweating can provide rapid evaporative cooling. It is regulated by impulses from the anterior hypothalamus. These impulses are transmitted in the autonomic pathways to the cord and from there through the sympathetic outflow to the skin of all regions of the body.

Regulation of the body temperature is a function of the hypothalamus. The hypothalamus regulates the body temperature by controlling the rates of heat production and heat loss. Neurones which regulate body temperature are situated in the anterior hypothalamus. ${ }^{11}$

What goes on in the hypothalamus to bring about this regulation? The recorded experiments suggest that it is the release of adrenaline, noradrenaline, and 5-hydroxy tryptamine. These experiments are the outcome of two independent observations: (1) Pyrogens injected into the cerebral ventricles ${ }^{12}$ or directly into the anterior hypothalamus cause fever and shivering. (2) When amines are similarly injected, 5-hydroxytryptamine produces shivering, whereas adrenaline and noradrenaline abolish induced shivering. ${ }^{13-16}$ There are two possible ways in which amines may affect body temperature: $(a)$ they may be continuously released, the normal temperature control being a fine balance between the release of 5-hydroxytryptamine, of adrenaline, and of noradrenaline. Change in temperature would then be brought about by disturbance in this balance. Alternatively, (b) normal temperature is maintained independent of release of the three amines, their release being the mechanism by which changes in temperature are effected.

Pyrogens may influence release of 5-hydroxytryptamine, or render the hypothalamus more sensitive to 5 -hydroxytryptamine. They may also mimic the action 
of 5-hydroxytryptamine. There is evidence that amines affect the body temperature by both heat production and heat elimination.

Rise in temperature is associated with shivering and vasoconstriction. Fall produced by adrenaline and noradrenaline is associated with dilatation of vessels and a decrease in muscle tone. It is not known whether the heat production in liver changes during hyperthermia. Findings reported suggest that normal temperature is maintained by a delicate balance in the release of adrenaline, noradrenaline, and 5-hydroxytryptamine in the hypothalamus, thus attributing an important physiological function to the presence of these amines in this part of the brain. This, however, may not be their sole function. Only when the temperature has first been elevated is the effect of adrenaline and noradrenaline in lowering the body temperature evident. The reason may be that these amines are continuously in sufficient amounts in the hypothalamus to keep the body temperature down, in the same way as their release is thought to prevent continuous shivering. ${ }^{17}$ Additional adrenaline or noradrenaline applied artificially to the anterior hypothalamus would have no action either on temperature which is already down or on shivering, which is not present.

What happens to the temperature-regulating mechanism during anaesthesia? There are few actual data available about the action of anaesthetic agents on temperature-regulating mechanisms. In anaesthesia the regulation of temperature is usually abolished. The temperature falls if no external heat is applied. This fall is apparently due to the direct effect of anaesthetic agents on the hypothalamus. ${ }^{18}$ However, it cannot be explained by the fact that the anaesthetic agents render the hypothalamus insensitive to amines, for it has been shown that the hypothalamus retains its sensitivity to amines under anaesthesia. ${ }^{10} \mathrm{We}$ would have to assume that anaesthetic agents act by modifying the release of amines in these areas. This would also explain the difference between the effect of anaesthetic agents on the temperature-regulating mechanism. Pentobarbitone, for example, clearly has a pyrogenic effect. The initial fall in temperature after its injection is followed by a rise to fever level and is associated with vigorous shivering. ${ }^{20}$ This shivering has been shown to be abolished by small amounts of adrenaline and noradrenaline given intraventricularly. ${ }^{15}$ In the process of studying the functions of the cerebrospinal fluid it has been shown that many drugs, when carried to the brain via the cerebrospinal fluid, have powerful effects which often bear no relation to the effect these drugs have on the brain when they reach it via the blood stream. For example: d-tubocurarine injected into the cerebral ventricles causes mydriasis, rise in arterial blood pressure, salivation, shivering, increased reflex, muscular excitability, myoclonic jerks, increase in depth and rate of respiration. ${ }^{21}$ Decamethonium similarly causes tremor and spasticity, salivation, tachypnea. ${ }^{21}$

Acetylcholine will cause muscle twitching and tonoclonic fits. ${ }^{22}$ It is obvious that our knowledge in this area is still very meagre. All experiments done to date have been purely pharmacological. To prove them, it would be necessary to demonstrate the release of amines during anaesthesia and simultaneously to observe the temperature changes. 


\section{The Effect of Hyperthermia on the Body}

Hyperthermia represents a marked failure of heat-regulating mechanisms to maintain proper balance between heat gain and heat loss. The chief contributing factors, of which one or all can be operative, are: $(a)$ decreased heat loss (lack of sweat glands, inhibition of sweating, inadequate peripheral circulation, high environmental temperature, increased humidity); (b) increased heat absorption, due to high environmental temperature; $(c)$ interference with the heat regulating centre. Once the body temperature rises the metabolism in all cells of the body increases. There is a limit to the rate of heat loss, even when the heat loss mechanisms are all functioning. Furthermore when the hypothalamus is overheated it functions very poorly. A vicious circle results. Once the body temperature rises above $110^{\circ} \mathrm{F}$. and the body is unable to rid itself of excessive heat, death will result, unless the rise is checked artificially. Some experimental studies have been done to investigate the aetiology and effects of hyperthermia. Animals were made hyperthermic and, after they died, detailed autopsies were performed, followed by meticulous patho-histological examinations, especially of the brain. ${ }^{23}$ There is also a study of 125 fatal cases of hyperpyrexia among United States servicemen. Detailed study of their histories and their symptomatology, followed by detailed pathological examinations is included.24 Another report of a large number of hyperpyrexia cases mainly describes the symptomatology ${ }^{25}$

The common denominator of these studies is that no specific lesion could be found on gross or microscopic examination of the organs. This applies to both animals and humans. The changes were mainly those which can be found in fatal cases due to hypoxia. It has been found that the liver is sensitive to hyperthermia, especially when associated with hypoxaemia. There is a marked destruction of hepatic cells, reflected by the elevation of enzymes. ${ }^{26} \mathrm{It}$ has been also shown that during hyperthermia there is a marked elevation in catecholamine and histamine levels in plasma. The increased level of catecholamines is likely of adrenal origin. Noradrenaline has been implicated as the agent inducing an increase in plasma histamine levels. Histamine has many potential vascular actions which could contribute to the cardiovascular collapse. ${ }^{27}$ Circulation of increased catecholamines may also be detrimental rather than beneficial. Catecholamines are known to cause cardiac lesions and lesions in other organs. ${ }^{28}$ Increased catecholamines may also be in part responsible for the body's inability to compensate for the increased heat load during hyperthermia. There is also evidence that histamine produces tolerance to noradrenaline. ${ }^{27}$ As mentioned before, a rise in body temperature will increase the metabolism of all the cells, resulting in greater oxygen consumption and relative hypoxia, and in an increase of waste products. This, together with poor tissue perfusion because of severe vasoconstriction or, in later stages, cardiovascular collapse, will result in acidosis. The direct damage of tissues which follows is a mixture of $(a)$ protein denaturation, $(b)$ enzyme degradation, $(c)$ alteration in physical structure of the cell membrane, $(d)$ change in viscosity of the cell protoplasm. ${ }^{20}$

All these changes added together, plus decreased responsiveness to catecholamines, ${ }^{30}$ will eventually lead to cardiovascular collapse and death. In trying to 
treat these patients successfully one has first to anticipate these "idiopathic" hyperthermias. The actual treatment will remain symptomatic until we learn more about the aetiology of hyperthermia during anaesthesia. The main points in treatment are: $(a)$ artificial lowering of body temperature, $(b)$ prevention of hypoxia, (c) treatment of acidosis, (d) treatment of hypovolaemia, $(e)$ prevention and treatment of cerebral oedema, $(f)$ treatment of known contributory factors and/or aetiological factors such as infection.

\section{RÉSUMÉ}

Il s'agit d'un jeune homme de 22 ans selon toute apparence en bon état général. Ce malade a été admis à l'hôpital pour correction chirurgicale de difformité équino-varus de ses pieds.

L'histoire antérieure révèle que le malade est né avec des difformités aux deux pieds, une scoliose et une ptose légère de la paupière droite. Alors qu'il était enfant, il a été admis plusieurs fois à l'hôpital pour enfants malades de Toronto à cause de troubles aux pieds et il a subi deux anesthésies sans incident pour des opérations aux yeux à l'âge de 6 et de 7 ans. C'est tout ce qui peut offrir de l'intérêt dans son histoire. Histoire de famille: le père de l'enfant avait également une légère difformité de la colonne, les autres membres de la famille sont en santé.

L'examen physique révèle que le jeune homme est en santé, un peu maigre, mais bien développé et porteur de difformités musculosquelettiques mentionnées antérieurement. Le reste de l'examen est normal. Hb. 14.5 gm., G.B. 10700, V.S. $17 \mathrm{~mm}$./h.

Comme prémédication, il a reçu, une heure avant l'opération: mépéridine $75 \mathrm{mg}$. et atropine $0.4 \mathrm{mg}$. en injection intramusculaire. A son arrivée a la salle d'opération, sa température était de $97.4^{\circ} \mathrm{F}$., sa pression $120 / 88$, son pouls 90 par min. L'induction de l'anesthésie a été faite avec $250 \mathrm{mg}$. de thiopentone et le maintien avec du protoxyde d'azote et de l'oxygène (à un débit de 4 litres chacun) et de l'halothane en circuit semi-ferme avec absorption et en respiration spontanée. Du glucose 5 pour cent dans l'eau a été administré par voie endoveineuse dans l'avant-bras gauche du malade. On a installé un tourniquet sur la cuisse droite du malade.

Vingt-cinq minutes après le début de l'induction de l'anesthésie la respiration s'est avérée inadéquate. On a vérifié la perméabilité des voies respiratoires sans déceler d'obstruction et le fait de donner une nouvelle position à la tête n'a pas amélioré la situation. A ce moment-là, la malade a semblé présenter un bronchospasme, chose qui a été confirmée par lauscultation du thorax. Finalement, à l'aide d'un myorésolutif, on a intubé le malade avec un tube Magill No. 9 et on a assisté la respiration. Dans une tentative de faire céder le bronchospasme, on a fait inhaler des vapeurs d'éther, mais cela n'a pas réussi. Le malade est devenu rouge mais sans transpiration. En vérifiant la température du malade, on a trouvé qu'elle était de $104^{\circ} \mathrm{F}$. On a discontinué l'éther, on a donné $20 \mathrm{mg}$. de succinylcholine par voie endoveineuse, ce qui n'a rien changé. On a discontinué l'administration des agents anesthésiques et on a continué la ventilation, avec de l'oxygène pure et de la pression positive intermittente. La température du malade 
s'est élevée à $108^{\circ} \mathrm{F}$. et après quelques minutes à $110^{\circ} \mathrm{F}$. On a commencé le refroidissement artificiel avec des vessies de glace, des compresses d'alcool et, plus tard, une irrigation glacée du colon. On a changé l'infusion endo-veineuse par crainte que la première installée n'ait contenu des pyrogènes.

Les pupilles sont devenues dilatées et ne réagissaient plus à la lumière. Les bras et les jambes sont devenus rigides en spasme carpopédieux. Les orteils étaient en érection. Les muscles abdominaux étaient contractés et le malade a présenté du trémor et des mouvements myocloniques. Ultérieurement il a présenté de l'épisthotonos. Le pouls s'est accéléré jusqu'à 130 par min. puis cette tachycardie a été suivie de bradycardie et d'arythmie. Un souffle systolique est apparu. On a pris un tracé électrocardiographique qui a passé d'un blocage de la branche droite du faisceau a une tachycardie ventriculaire et des changements typiques d'ischémie myocardique. La tension artérielle est demeurée aux environs de 130/90 mm. de $\mathrm{Hg}$ jusqu’à la fin, alors elle est tombée soudainement et le cour s'est arrêté: 3 heures et $45 \mathrm{~min}$. après le début de linduction de l'anesthésie.

$\mathrm{Au}$ cours de ce délai, les autres traitements ont consisté en: cortisone (Solucortef) $500 \mathrm{mg}$., tétracycline $275 \mathrm{mg}$. par voie endoveineuse, mannitol 10 pour cent $1000 \mathrm{ml}$. A la mort, la température rectale était de $104^{\circ} \mathrm{F}$.

$\mathrm{La}$ culture sanguine et des cultures de tous les médicaments employés, des solutions endoveineuses et de toutes les seringues employées ont été négatives. Toutes les solutions étaient dépourvues de pyrogène.

L'autopsie n'a révélé aucune lésion spécifique. Il y avait de l'œdème cérébral et des pétéchies hémorragiques sur le cerveau et sur les muqueuses.

\section{REFERENCES}

1. Buprond, G. E. Hyperthermia following Anesthesia; Consideration of Control of Body Temperature during Anesthesia. Anesthesiology. 1: 208 (1940).

2. Ruttle, Lawrence D., ed. Case report no. 247: Death Occurred in the Operating Room following Extreme Hyperthermia during an Elective Cholecystectomy. Am. Soc. Anesth. Newsletter. 26: 21 (1962).

3. - Case report no. 247. Comment by "P.S.M." Am. Soc. Anesth. Newsletter. 26: 10 (1962).

4. SaIdman, L. J.; Havard, E. S.; \& EgEn, E. I. 2d. Hyperthermia during Anesthesia. J.A.M.A. 190: 1029 (1964).

5. Stantey, B. \& PaL, N. R. Fatal Hyperpyrexia with Phenelzine and Imipramine. Brit. Med. J. 5415: 1011 (1964).

6. Lewis, E. Hyperpyrexia with Antidepressant Drugs. Brit. Med. J. 5451 : I671 (1965).

7. Bagdon, Walter J. \& MaNN, David E., Jr. Factors Modifying Chlorpromazine Hyperthermia in Young Albino Mice. J. Pharmaceut. Sci. 54: 240 (1965).

8. Zrvin, I. \& ShatowTtz, M. Acute Toxic Reaction to Prolonged Glutethimide Administration. New England J. Med. 266: 496 (1962).

9. McBay, A. J. \& Katsas, G. G. Glutethimide Poisoning; a Report of Four Fatal Cases. New England J. Med. 257: 97 (1957).

10. KIER, L. C.; WhITEheAd, R. W.; \& WhITE, W. C. Blood and Urine Levels in Glutethimide (Doriden) Intoxication. J.A.M.A. 166: 1861 (1958).

11. Feldberc, W. \& Fleischinuen, K. A New Experimental Approach to the Physiology and Pharmacology of the Brain. Brit. Med. Bull. 21: 36 (1965).

12. Sheth, U. K. \& Boruson, H. L. Central Pyrogenic Action of Salmonella Typhosa Lipopolysaccharide Injected into the Lateral Cerebral Ventricle in Cats. J. Pharmacol. \& Exper. Therap. 130: 411 (1960).

13. Carmichaed, E. A.; Feldberg, W.; \& Fleischinauer, K. The Site of Origin of the 
Tremor Produced by Tubocurarine Acting from the Cerebral Ventricles. J. Physiol. 162: 539 (1962).

14. Fezdaerc, W. \& MaLcolm, J. Experiments on the Site of Action of Tubocurarine when Applied via the Cerebral Ventricles. J. Physiol. 149: 58 (1959).

15. Domen, F. R. \& FELDBERc, W. Tremor in Cats: The Effect of the Administration of Drugs into the Cerebral Ventricles. Brit. J. Pharmacol. 15: 578 (1960).

16. Feldeerg, W. \& Myers, R. D. Effects on Temperature of Amines Injected into the Cerebral Ventricles. A New Concept of Temperature Regulation. J. Physiol. 173: 226 (1964).

17. FeldeErg, W. A Pharmacological Approach to the Brain from its Inner and Outer Surface. London: Arnold (1963).

18A.Ferdberc, W. \& Myers, R. D. Fall of Temperature Produced by Chloralose Acting on the Hypothalamus. J. Physiol. 177: 25P (1965).

B. Feldaerc, W. \& Myers, R. D. Changes in Temperature Produced by Micro-injections of Amines into the Anterior Hypothalamus of Cats. J. Physiol. 177: 239 (1965).

19. Ferdberg, W. \& Myers, R. D. Temperature Changes Produced by Amines Injected into the Cerebral Ventricles during Anaesthesia. J. Physiol. 175: 464 (1964).

20. Lippold, O. C.; ReDfensR, J. W.; \& Vuco, J. The Influence of Afferent and Descending Pathways on the Rhythmical and Arrhythmical Components of Muscular Activity in Man and the Anaesthetized Cat. J. Physiol. 146:I (1959).

21. Feldberg, W. \& Sherwood, S. L. Injections of Drugs into the Lateral Ventricle of the Cat. J. Physiol. 123: 148 (1954).

22. - Intraventricular Injections of Acetylcholine and of 5-Hydroxytryptamine (Serotonin) into the Conscious Cat. J. Physiol. 120: 12P (1953).

23. ALlEN, INGRD V. Cerebral Changes in Experimental Heatstroke. Irish J. M. Sci. 6th ser.: 413 (1964).

24. Mazamod, N.; Haxmaren, W.; \& CuSTER, R. P. Heat Stroke: Clinicopathologic Study of 125 Fatal Cases. Mil. Surgeon. 99: 397 (1946).

25. Kumar, Prem; Rathore, C. K.; Nagar, A. M.; \& Mehrotra, M. P. Hyperpyrexia with Special Reference to Heat Stroke. Journal Indian M. A. 43: 213 (1964).

26. Reen, W. A.; Manning, R. T.; \& Hopkins, L. T., JR. Effects of Hypoxia and Hyperthermia on Hepatic Tissue of the Dog. Am. J. Physiol. 206: 1304 (1964).

27. Coprola, J. A. \& Di PaLMA, J. R. Histamine as a Fatcor in Tolerance to Levarterenol. Am. J. Physiol, 202: 114 (1962).

28. Szaracs, J. E. \& Mrmiman, B. Pathologic Changes Induced by 1-Norepinephrine: Quantitative Aspects. Am. J. Cardiol. 5: 619 (1960).

29. Handooor of Physiology. Section 4: Adaptation to the Environment. Lee, Dougras H. K. Terrestrial Animals in Dry Heat: Man in the Desert. Am. Physiol. Society, Washington (1964), 551-582. (Distributed by William \& Wilkins.)

30. Smalt, Harold S.; Weitzener, Stanley W.; \& Nafas, Gabruel G. Cardiovascular Effects of Levarterenol, Hydrocortisone Hemisuccinate and Aldosterone in the Dog. Am. J. Physiol. 196: 1025 (1959).

31. Feldaerg, W. \& Myers, R. D. A New Concept of Temperature Regulation by Amines in the Hypothalamus. Nature. 200: 1325 (1963).

32. GuYron, Arthun C. Textbook of Medical Physiology. 2nd ed. Philadelphia: Saunders (1961). 